\title{
Implementation of Think Pair Share (TPS) Cooperative Learning Model to Improve Students' Mathematical Connection Ability
}

\section{Abd. Qohar ${ }^{*}$, Abdul Rozak ${ }^{2}$}

1,2 Mathematics Department, Universitas Negeri Malang, Malang, Indonesia

A R T I C L E I N F O

Article history:

Received 18 December 2020

Received in revised

Form 06 January 2021

Accepted 1 February 2021

Available online 09

February 2021

Keywords:

Mathematical

Connection:

Think-Pair-Share (TPS)

\section{A B S T R A C T}

This study aims to describe the application of Think Pair Share (TPS) cooperative learning models to improve students 'mathematical connection abilities on derivative material. The mathematical connection indicators in this study are (1) the ability of mathematical connections between mathematical topics, (2) the ability of mathematical connections with other subjects, (3) the ability of mathematical connections with problems in daily life. This research is a class action research (CAR) conducted in class XI-G4 SMA Negeri 5 Malang in two cycles. The first cycle was carried out in five meetings, four meetings for the implementation of learning and one meeting for the final test of the first cycle. Whereas in the second cycle held in five meetings, namely four meetings for the implementation of learning and one meeting for the final test of the second cycle. The results of the research showed that an increase in students' mathematical connections from cycle I to cycle II was indicated by an increase in the grade average and the percentage of completeness in class learning. The classical average in cycle I was 82.79 and increased by 8.56 to 91.35 in cycle II, and the percentage of completeness in cycle I was $70.59 \%$ from 34 students and increased by $11.76 \%$ to $82.35 \%$ of 34 students in the second cycle. The results imply that the TPS type of cooperative learning model is recommended to improve students' mathematical connections in mathematics teaching and learning.

\section{Introduction}

Mathematics is one of the lessons learned by students that starts from Elementary Schools, Middle Schools and even Universities. The National Council of Teachers of Mathematics (NCTM, 2000) states that in mathematics learning activities must pay attention to mathematical connection ability. Surya and Maisyarah (Maisyarah \& Surya, 2017) state that the ability of mathematical connections is the ability to connect mathematical concepts, both between mathematical concepts themselves and with other fields (with other subjects and with real life). There are three indicators that show students' mathematical connection abilities, namely: aspects of connections between mathematical topics, aspects of connections with other subjects, and aspects of connections with everyday life (Afifah, 2017). In addition, (Walle, 2008) explained that the connection standard has two parts. First, standards pertain to relationships within and between mathematical ideas. For example, fractions are connected with the concepts of decimal and percent. Students need help to see how mathematical concepts are built from one idea to another in a network of ideas connections. Second, mathematics must be connected with the real world and other disciplines. Students as far as possible see that mathematics has a significant role in the arts, science, languages, and social sciences. This suggests that mathematics is often associated with other disciplines and the application of mathematics can be investigated in real world contexts. Based on this explanation, the ability of mathematical connections is an ability that needs more attention in learning activities.

Problems about the lack of students' mathematical communication skills are often found in learning in schools. This is like what happened in the XI-G4 class of SMAN 5 Malang, when assigning the Quiz material Limit to the algebraic function, some students' answers were found that had not been able to link the concept of the function and the concept of the limit. Here are some students' answers to question number 5 . 
5. Let $f(x)=\left\{\begin{array}{c}4 x-3 \text { if } x \geq 2 \\ x^{2}-7 x+2 \text { if } x<2\end{array}\right.$

Choose the following statements that are true:
a. $\lim _{x \rightarrow 4} f(x)=12$
c. $f(0)=3$
b. $\lim _{x \rightarrow 2} f(x)=$ no limit
d. $f(3)=12$

Figure 1. Problem Number 5

From the question in Figure 1, one of the answers of students who experience a mathematical connection error can be seen in Figure 2.
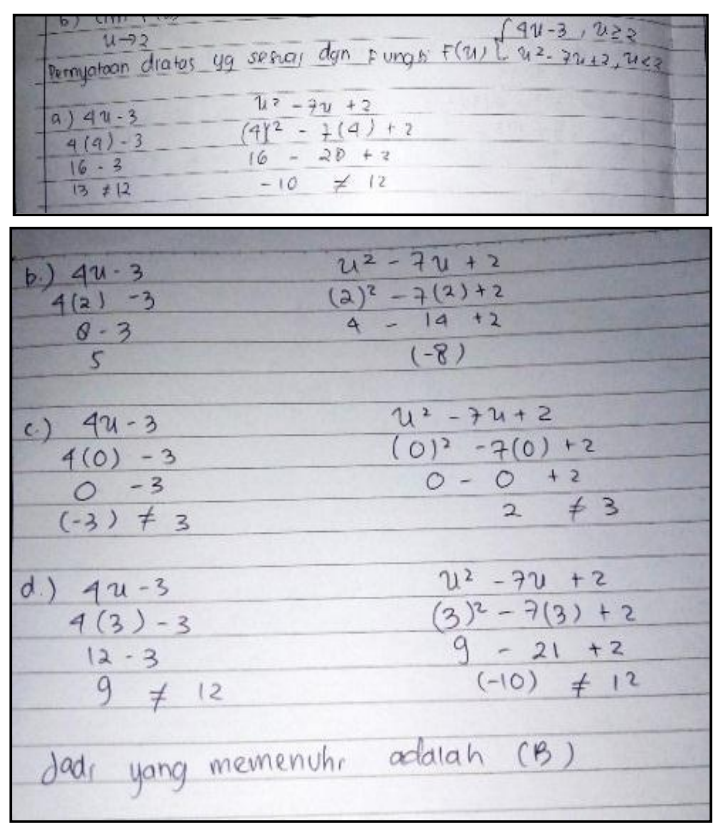

Figure 2. Student-A Mathematical Connection Error

In Figure 2, students do not do analysis through graphs and done directly (for questions a and b), this causes students to answer incorrectly. The mathematical connection contained in this problem is in the activity of describing the function piecewise to determine the limit of the function at a certain value $x$.

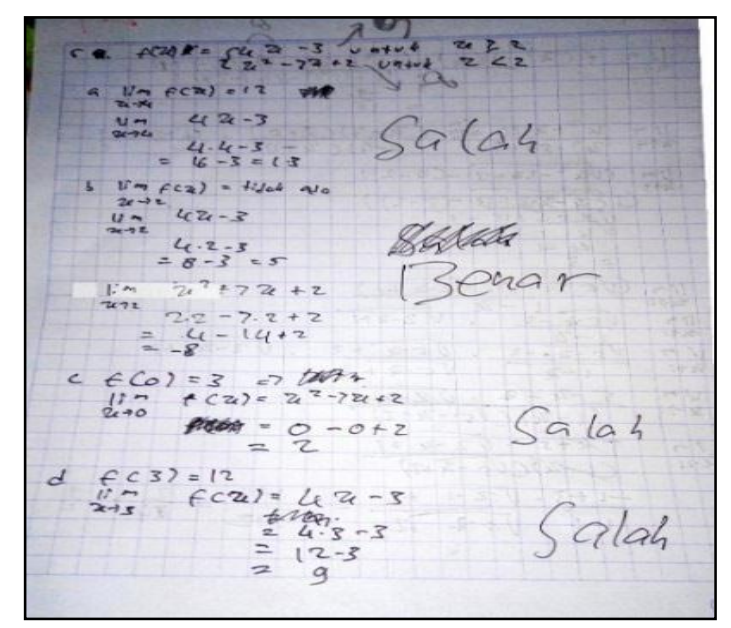

Figure 3. Student-B Answer (correct) in Answering Problem Number 5 
Student B answers using problem analysis directly without having to draw a graph of the function piecewise. This is allowed as long as students analyze accurately based on the questions given. In Figure 3. the students can determine that to determine questions at the student uses the function $\mathrm{f}(\mathrm{x})=4 x-3$, this is because " $x \geq 2$ ".

Based on the results of the work on the problem, it is found students who are unable to associate the concept of limits with algebraic functions to solve mathematical problems. In this case, the connection (relation) of the function concept to the limit concept is to determine the limit on the function, an approach should be made on the $x$ that will be approached so that it is close to the $x$ (from right and left).

Furthermore, it is also known that 13 out of 34 students in class XI-G4 answer the question number $5 \mathrm{~b}$ in substitution without regard to or associate with the concept of limits that they learned in the previous meeting. This causes students to tend to answer directly and inaccurately. Some possible causes of the problem are as follows 1) Students do not understand the concept of functions, 2) Students' mathematical connection ability is still low, 3) Students get answers from cheating. Here are some alternative solutions to the problem above 1) Explain in detail about the concept of function, 2) Increase the practice of questions, 3) Use the right learning model and can improve students' mathematical connections, 4) Make 2 or more types of questions. One solution offered by researchers is through the application of cooperative learning methods.

Cooperative learning model is a model that emphasizes the existence of groups with different abilities, cooperate with each other, exchange ideas, and are responsible for the achievement of learning outcomes, both individually and in groups (Kamal, 2016). Some researchers such as (Gokkurt et al., 2012; Hossain \& Tarmizi, 2013; Jumarniati et al., 2018; Lavasani \& Khandan, 2011; Pawattana et al., 2014) have chosen cooperative learning models in their research and obtained good results. In addition, based on (Aziz \& Hossain, 2010) research comparing cooperative learning and conventional teaching, the result is that cooperative learning can improve student mathematics achievement and student performance for the better.

One type of cooperative learning is Think-Pair-Share (TPS). This TPS has several advantages including, among others, Sinaga and Karnasih (Karnasih \& Sinaga, 2014) in the results of their research which showed that there was an increase in students 'mathematical connection skills and improved students' mathematical problem solving abilities and mathematical connections. In addition, (Armawan \& Sugita, 2014) explained that the application of the TPS type of cooperative learning model can improve student learning outcomes in class VIII of SMPN 7 Palu. Furthermore, (Patrianto et al., 2012) stated that there was an increase in students' learning completeness after learning using the TPS method. Discussion activities in TPS have a pretty good effect on students' mathematical abilities. This is supported by Lee's statement (Lee, 2006) that increasing conversation in class is a potential that can help students to connect between concepts in mathematics learning.

Based on the description above, the researchers determined to use appropriate learning models and can improve students' mathematical connection skills. This is for the reason that the determination of the right learning model and can improve students' mathematical connection ability is a solution or solution that generally can solve the causes of the problems mentioned above. The model chosen by the researcher in this case is the TPS type of cooperative learning model.

This study aims to describe the application of Think Pair Share (TPS) cooperative learning models to improve students 'mathematical connection abilities on derivative material.

\section{Methods}

This type of research is classroom action research. Classroom action research design that is used as a reference for this research is using Kurt Lewin's model. According to (Uno et al., 2012) that the main concept of Kurt Lewin's research consists of four components, namely; a) planning, b) action, c) observation, and d) reflection. This research was conducted at SMA Negeri 5 Malang. The subjects of this study were 34 students of class XI-G4.

Data collection techniques in this study include observation, documentation, and mathematical connection tests. The data analyzed in this study are (1) Observation of teacher activities, (2) Observation of student activities, and (3) Tests of students' mathematical connections on derived material.

The research procedure was carried out in four stages, namely as follows: 1) The planning stage, at this stage the preparation of lesson plans, worksheets on derivative topics was carried out, preparing research instruments in the form of student and teacher activity observation sheets. 2) The implementation stage, at this stage all learning activities in the classroom are in accordance with the planning stage. 3) The observation stage, the observation is made by the observer, where the observer is in charge of recording all activities during the learning process. The results of the observations were 
recorded on the teacher activity observation sheet, the student activity observation sheet inside and outside the group, and the field note format. 4) The reflection stage, this stage is carried out at the end of each learning implementation by means of each observer explaining the results of his observations during the learning activity then the researcher confirms and checks the suitability of the data.

Furthermore, the researcher analyzed the results of action 1 as a consideration whether the cycle had reached the criteria or not. If the criteria for action have been met, the research is considered complete. Conversely, if the success criteria are not achieved, the researcher repeats the action and fixes any weaknesses that exist in the next cycle.

\section{Result and Discussion}

This research was conducted in 2 cycles, cycle I consisted of 5 meetings, consisted of 4 learning activities meetings and 1 meeting was the final test of cycle I. This also applies in cycle II but for discussion of different material. Each meeting is held in $2 \times 45$ minutes.

In cycle I, students learn material about introductory derivatives. At the first meeting students learn about "the definition of the derivative as a function limit through the concept of the slope of the secant and tangent line", at the second meeting students learn about "determining the properties of the algebraic function derivative using the definition of derivatives", at the third meeting students learn about "determining derivatives of an algebraic function by using the properties of algebraic function derivatives", at the fourth meeting students learned about" solving problems related to algebraic function derivatives by using the properties of algebraic function derivatives ". at the fifth meeting students are given final test questions in cycle I.

Meanwhile, in cycle II, students learn material about introductory derivatives. At the first meeting students learn about "linking the concept of derivatives to determine tangent lines and normal lines", at the second meeting students learn about "determining the upward function or downward function of a curve through a derivative concept", at the third meeting students learn about "determining the speed of an object moving ", at the fourth meeting students learn about" solving problems related to the optimization of everyday problems with a derivative concept ". at the fifth meeting students were given the final test questions on cycle II. The following is a graphic image of the percentage of research results.

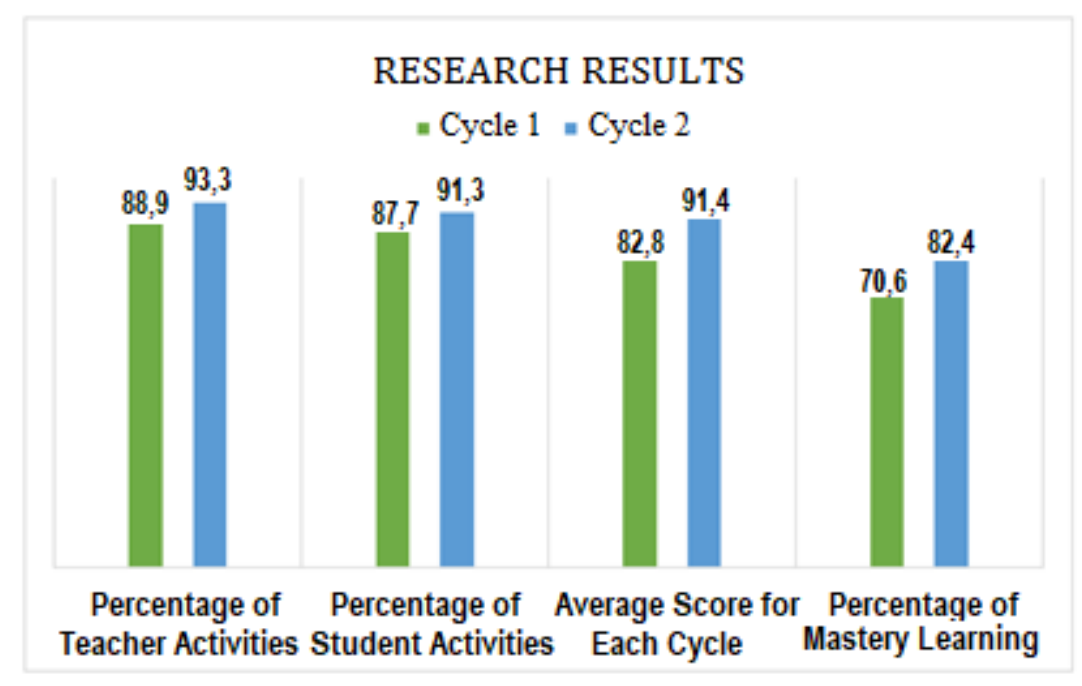

Figure 4. Research Results

During the learning activities cycle I and II took place also conducted observations of teacher activities. Based on Figure 4. the percentage of the implementation of learning activities with the type of TPS cooperative learning model in the first cycle is $88.94 \%$ with the category "Very Good". While in the second cycle the percentage increased to $93.27 \%$ with the category "Very Good". In implementing learning activities, researchers also ask observers to provide special notes which are then used as field notes. Based on the field notes, it was found several things that needed improvement, in the first cycle including (1) the teacher should ask the attention of students to focus on learning activities, (2) students are confused in understanding the instructions in the worksheet, (3) worksheets to be presented more gradually to avoiding the confusion of students, (4) teachers should monitor every student learning 
activity, (5) apperception activities should be increased again, (6) questions on Quis activities should pay attention to time allocation. While in cycle II, the things that need to be considered are: (1) the teacher should ask the attention of students to focus on learning.

Furthermore, in this study also conducted data collection on student activities in learning. Based on Figure 4. the percentage of student activities in the first cycle was $87.87 \%$ with the category "Very Good", then in the second cycle there was an increase to $91.29 \%$ with the category "Very Good". Both in cycle I and II students are quite active in learning activities by using TPS cooperative learning models. Students also actively submit responses during the Share activity phase.

The essence of this research is to find out whether or not there is an increase in students' mathematical connections after the implementation of the TPS type cooperative learning model. Based on Figure 4. At the end of the first cycle test of 34 students who took the final cycle test, data obtained that many students who completed were 24 students and many students who did not complete as many as 10 people, while the percentage of completeness was $70.59 \%$ and the average class is 82.79 . Because the results of the first cycle have not yet reached the achievement indicator, the researchers decided to carry out the second cycle. At the end of the second cycle test of 34 students who took the final test cycle obtained data that many students who completed were 28 students and many students who did not complete as many as 6 people. While the percentage of completeness is $82.35 \%$ and the class average is 91.35. This is consistent with the indicators set by researchers that students' mathematical connections are said to increase if $75 \%$ of all students have achieved grades of at least 83.

Following is an example of the results of one of the students who experienced an increase in mathematical connections after applying the TPS type cooperative learning model for two cycles.

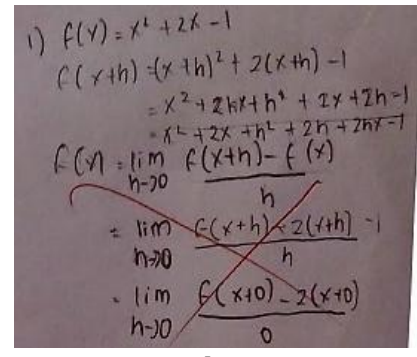

a. Cycle 1

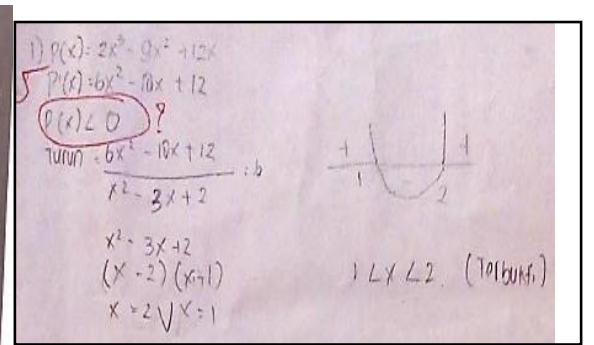

b. Cycle 2

Figure 5. Student Work Results in Problem Number 1 in Cycle 1 and Cycle 2

In Figure 5.a the students in cycle I have not been able to relate the concept of the derivative through the limit correctly, even though they are able to remember the derivative formula. But in Figure 5.b, in cycle II the student has succeeded in connecting the derivative concepts he has learned before, to prove the descending function on a curve even though there is a slight error in writing down the condition for the descending function.

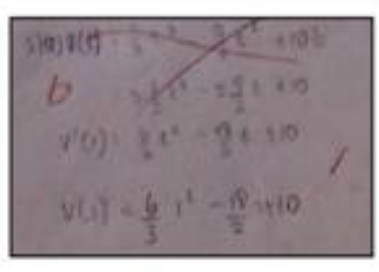

Cycle 1

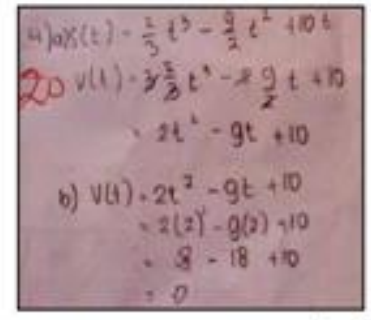

Cycle 2

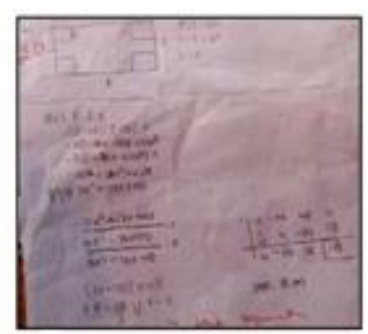

Figure 6. Student Work Results in Problems Number 3, 4, and 6 that Have Increased Mathematical Connections

In Figure 6.a, in cycle I students have not been able to relate the concept of derivatives to contextual problems. Students cannot understand the problem that speed is the first derivative of the distance function of a moving object. However, in Figure 6.b in cycle II, students show the development or improvement of mathematical connection abilities. Students can understand the instructions of students and are able to connect the concept of derivatives into the concept of speed and the concept of maximizing 
the volume of flat objects precisely. This shows that students have a business that is really serious and at the same time enjoy the learning activities that have been carried out by the teacher. Mathematical connections can increase, mostly due to the active share of the teacher scaffolding the pair of students who are experiencing difficulties and due to the willingness of students to consciously exchange opinions in that stage. This is in accordance with research by (Apte \& Bhave-Gudipudi, 2020; Thurston et al., 2019) which states that cooperative learning can bridge students with high and low abilities by exchanging opinions so that their academic abilities increase. Student success is also influenced by teacher guidance and belief in student success (Perera \& John, 2020).

Based on the results of the study above, it was found that: (1) the implementation of learning with the type of cooperative learning model in cycle I and cycle II had fulfilled good criteria, (2) student activities in applying the type of cooperative learning model in cycle I and cycle II had meet good criteria, (3) the percentage of students' mastery learning has increased from cycle I to cycle II. These results are in line with research (Segundo Marcos et al., 2020; Van Ryzin \& Roseth, 2019; Veldman et al., 2020) and (Asmar \& Awuy, 2016) which states that cooperative learning can improve student learning outcomes.

Because the research results obtained have met the indicators of success, it can be reported that the Classroom Action Research (CAR) was successful. In addition, the application of the TPS type of cooperative learning model can also improve students' mathematical connections. The increase in students' mathematical connections can be seen in the average results of the end of the first cycle test which is 82.79 and the percentage of completeness $70.59 \%$ increased in the second cycle which obtained an average end of the second cycle test that is 91.35 and the percentage of completeness $82.35 \%$. This is consistent with the indicators set by researchers that students' mathematical connections are said to increase if $75 \%$ of all students have reached a value of at least 83 . Mathematical connections can increase, largely due to the active share of the teacher schaffolding students to pairs of students who experience difficulty and is caused by the willingness of students to consciously exchange opinions in that stage. The results of this study are supported by research conducted by (Karnasih \& Sinaga, 2014) which concluded that there was an increase in students' mathematical connection abilities after the application of the TPS learning method.

In addition, Sujana and Maskhopipah also concluded that there was an increase in problemsolving abilities (continued effects of mathematical connections) after the application of this type of cooperative learning model (Sujana \& Maskhopipah, 2017). Furthermore, Rifa'i and Lestari stated in their research that TPS has a significant effect on students' self-confidence and problem solving abilities, this is a further effect of TPS besides being able to improve mathematical connections (Rifa'i \& Lestari, 2018). With the increasing ability of students' mathematical connections, then automatically trust and problem solving abilities of students. Furthermore, Afthina, Mardiyana, and Pramudya also stated that the strong influence of TPS is that students can learn more actively and understand the material more deeply, and mathematics learning becomes more meaningful (Afthina et al., 2017).

Student activities in learning in the first cycle reached $87.87 \%$ with very good success rates. After being given the action cycle II student activities increased to $91.29 \%$ with a very good level of success. This level of success has met the established criteria, namely the observations of student and teacher activities in each action being in the good category. With an increase in student activity in this second cycle, so that the giving of action is stopped and it can be concluded that the application of the TPS type of cooperative learning model increases student activity in learning.

\section{Conclusion}

Based on the results of the study, it can be concluded that the implementation of Think-Pair-Share (TPS) type of cooperative learning models can improve the mathematical connections of class XI-G4 students of SMAN 5 Malang. The increase in students' mathematical connections can be seen in the average results of the end of the first cycle test which is 82.79 and the percentage of completeness $70.59 \%$ increase in the second cycle which obtained an average end of the second cycle test that is 91.35 and the percentage of completeness $82.35 \%$. The implementation of the activities of teachers in learning in the first cycle reached $88.94 \%$ with very good success rate of action. This percentage increased in cycle II to $93.29 \%$ with very good success rates. Student activities in learning in the first cycle reached $87.87 \%$ with very good success rates. After being given the action cycle II student activities increased to $91.29 \%$ with a very good level of success. Based on these conclusions, the TPS type of cooperative learning model can be used to improve students' mathematical connections. Teachers are advised to use the learning model as an alternative model of learning in the classroom to improve students' mathematical connection abilities. 


\section{References}

Afifah, R. N. (2017). Kemampuan Koneksi Matematis Pada Bangun Ruang Sisi Lengkung. Seminar Matematika Dan Pendidikan Matematika Uny, 619-624. http://seminar.uny.ac.id/semnasmatematika/sites/seminar.uny.ac.id.semnasmatematika/files/f ull/M-90.pdf

Afthina, H., Mardiyana, \& Pramudya, I. (2017). Think Pair Share Using Realistic Mathematics Education Approach in Geometry Learning. Journal of Physics: Conference Series. https://doi.org/10.1088/1742-6596/895/1/012025

Apte, M., \& Bhave-Gudipudi, A. (2020). Cooperative Learning techniques to bridge gaps in academia and corporate. Procedia Computer Science, 172(2019), 289-295. https://doi.org/10.1016/j.procs.2020.05.046

Armawan, I. M. A., \& Sugita, G. (2014). Penerapan Model Pembelajaran Kooperatif Tipe Think Pair Share (Tps) Untuk Meningkatkan Hasil Belajar Siswa Pada Materi Pemfaktoran Bentuk Kuadrat Di Kelas Viii Smpn 7 Palu. Jurnal Elektronik Pendidikan Matematika Tadulako, 2(2). http://jurnal.fkip.untad.ac.id/index.php/jpmt/article/view/233

Asmar, B. mallo, \& Awuy, E. (2016). Penerapan Model Pembelajaran Kooperatif Tipe Think Pair Share (Tps) Untuk Meningkatkan Hasil Belajar Siswa Pada Materi Penarikan Kesimpulan. Aksioma Jurnal Pendidikan Matematika, 5 Nomor 2.

Aziz, Z., \& Hossain, M. A. (2010). A comparison of cooperative learning and conventional teaching on student's achievement in secondary mathematics. Procedia - Social and Behavioral Sciences. https://doi.org/10.1016/j.sbspro.2010.12.115

Gokkurt, B., Dundar, S., Soylu, Y., \& Akgun, L. (2012). The Effects of Learning Together Technique Which is based on Cooperative Learning on Students' Achieevement in Mathematics Class. Procedia - Social and Behavioral Sciences. https://doi.org/10.1016/j.sbspro.2012.06.079

Hossain, A., \& Tarmizi, R. A. (2013). Effects of Cooperative Learning on Students' Achievement and Attitudes in Secondary Mathematics. Procedia - Social and Behavioral Sciences. https://doi.org/10.1016/j.sbspro.2013.09.222

Jumarniati, J., Ristia Kartika, D. M., \& Baharuddin, M. R. (2018). Penerapan Model Pembelajaran Kooperatif Pada Mata Kuliah Program Linear Melalui Lesson Study. MaPan. https://doi.org/10.24252/mapan.2018v6n2a5

Kamal, S. (2016). Implementasi Model Pembelajaran Think-Pair-Share (Tps) Untuk Meningkatkan Aktivitas Dan Hasil Belajar Siswa Kelas Xii Sma Negeri 10 Banjarmasin Tahun Pelajaran 2015/2016 Pada Materi Barisan Dan Deret. Math Didactic: Jurnal Pendidikan Matematika, 2(1), 111. https://doi.org/10.33654/math.v2i1.22

Karnasih, I., \& Sinaga, M. (2014). Enhancing Mathematical Problem Solving and Mathematical Connection Through the Use of Dynamic Software Autograph in Cooperative Learning Think-Pair-Share. SAINSAB.

Kunandar. (2010). Langkah Mudah Penelitian Tindakan Kelas sebagai Pengembangan Profesi Guru. Rajawali Press.

Lavasani, M. G., \& Khandan, F. (2011). The effect of cooperative learning on mathematics anxiety and help seeking behavior. Procedia - Social and Behavioral Sciences. https://doi.org/10.1016/j.sbspro.2011.03.085

Lee, C. (2006). Language for Learning Mathematics Assessment for Learning in Practice. Open University Press.

Maisyarah, R., \& Surya, E. (2017). Kemampuan Koneksi Matematis ( Connecting Mathematics Ability ) Siswa dalam Kemampuan Koneksi Matematis ( Connecting Mathematics Ability ) Siswa dalam Menyelesaikan Masalah Matematika. Jurnal Pendidikan Matematika, 2(1), 0-8.

NCTM. (2000). Principles and Standards for School Mathematics Overview. Journal of Equine Veterinary Science. 
Patrianto, U., Sa'dijah, C., \& Qohar, A. (2012). Penerapan Model Pembelajaran Kooperatif Tipe Think Pair Share untuk Memahamkan Materi Logaritma Kelas X SMKN 5 Malang. Jurnal Pendidikan Matematika, 1(1).

Pawattana, A., Prasarnpanich, S., \& Attanawong, R. (2014). Enhancing Primary School Students' Social Skills Using Cooperative Learning in Mathematics. Procedia - Social and Behavioral Sciences. https://doi.org/10.1016/j.sbspro.2014.01.1214

Perera, H. N., \& John, J. E. (2020). Teachers' self-efficacy beliefs for teaching math: Relations with teacher and student outcomes. Contemporary Educational Psychology, 61(January), 101842. https://doi.org/10.1016/j.cedpsych.2020.101842

Rifa'i, A., \& Lestari, H. P. (2018). The effect of Think Pair Share (TPS) using scientific approach on students' self-confidence and mathematical problem-solving. Journal of Physics: Conference Series. https://doi.org/10.1088/1742-6596/983/1/012084

Segundo Marcos, R. I., López Ferández, V., Daza González, M. T., \& Phillips-Silver, J. (2020). Promoting children's creative thinking through reading and writing in a cooperative learning classroom. Thinking Skills and Creativity, 36(June 2019), 100663. https://doi.org/10.1016/j.tsc.2020.100663

Sujana, A., \& Maskhopipah. (2017). Penerapan model pembelajaran kooperatif tipe Think Pair Share (TPS) Untuk meningkatkan hasil belajar siswa SMP. Pasundan Journal of Research in Mathematics Learning and Education, 2(1), 43-52.

Thurston, A., Cockerill, M., \& Craig, N. (2019). Using cooperative learning to close the reading attainment gap for students with low literacy levels for Grade 8/Year 9 students. International Journal of Educational Research, 94(February), 1-10. https://doi.org/10.1016/j.ijer.2019.02.016

Uno, H. B., Lamatenggo, N., \& Koni, S. M. (2012). Menjadi Peneliti PTK yang Profesional (2 ed.). Bumi Aksara.

Van Ryzin, M. J., \& Roseth, C. J. (2019). Cooperative learning effects on peer relations and alcohol use in middle school. Journal of Applied Developmental Psychology, 64(August), 101059. https://doi.org/10.1016/j.appdev.2019.101059

Veldman, M. A., Doolaard, S., Bosker, R. J., \& Snijders, T. A. B. (2020). Young children working together. Cooperative learning effects on group work of children in Grade 1 of primary education. Learning and Instruction, 67(February), 101308. https://doi.org/10.1016/j.learninstruc.2020.101308

Walle, J. A. (2008). Matematika Sekolah Dasar dan Menengah (Terjemahan) Jilid 1. Erlangga. 